\title{
THEN AND NOW: CHANGES IN SOCIAL ORGANISATION AND LIVELIHOOD OF THE BERAWAN COMMUNITY SINCE THE FORMATION OF MALAYSIA
}

\author{
Jey Lingam Burkhardt \\ Centre for English Language Studies, Sunway University, \\ Bandar Sunway, Malaysia \\ Jürgen Martin Burkhardt (PhD) \\ Fakulti Bahasa Moden dan Komunikasi, Universiti Putra Malaysia \\ Serdang, Malaysia \\ Email addresses:jeyanthia@sunway.edu.my / burkhardtjey@gmail.com
}

*Corresponding author

\begin{abstract}
The Berawan are a small Orang Ulu people group to which four longhouse communities belong: Long Jegan and Long Teru on the Tinjar River, and Long Terawan and Batu Belah on the Tutoh River. The Tutoh and the Tinjar are tributaries of the Baram river. This paper presents a socio-economic sketch of the Berawan in the early 1960s and contrasts it with the early 21 st century situation. A picture is drawn of the social organisation and livelihood of the Berawan community. The following trends are discernible: Longhouse living has become more comfortable but at the same time more cash dependent. The education level of the Berawan has risen significantly while their opportunities to engage in traditional livelihood activities such as rice planting, hunting and fishing are reduced nowadays due to the conversion of vast tracts of lands into palm oil plantations and the silting of the rivers. This has increasingly led the younger generation to migrate out of the village. On the other hand, contrary to popular belief that the tourism industry has a primarily adverse influence on ethnic minority culture, we found that the economic value that tourism offers can promote local culture in encouraging people to remain on their ancestral land.
\end{abstract}

Key words: Berawan, Orang Ulu, social organisation, livelihood, indigenous peoples, Sarawak 


\section{INTRODUCTION}

The last 50 years have seen major changes in livelihood and social organisation among Asian indigenous peoples. Many members of indigenous groups have left their rural dwellings and traditional lifestyle and moved to urban centres to seek work or business opportunities. The Malaysian state of Sarawak is no exception to this trend. From 1960 to 1991, the population rate of urban versus rural (in $\%$ ) changed from 10.8:89.2 to 37.5:62.5 for Sarawak in general and from 0.6:99.4 to 13.9:86.1 for 'other indigenous' groups in Sarawak, to which the Berawan belong (Soda, 2003).

The present study compares the social organisation and livelihood of the Berawan community in the early 1960s with their current situation. Section 2 outlines the methodology used in this study. Section 3 briefly describes the background of the Berawan people including their various communities and settlements today and the concept of communal belonging. Section 4 is divided into two parts: social organisation and livelihood - and compares the living condition and economic characteristics of the Berawan community before and after the formation of Malaysia. The major trends of changes among the Berawan communities are detailed in Section 5, before considering the communities' current aspirations as part of the mosaic of the multi-cultural, multi-ethnic and multi-linguistic nation of Malaysia in Section 6.

The data for this study were obtained from in-depth interviews with community leaders from each of the Berawan sub-groups: Long Terawan Berawan, Batu Belah Berawan, Long Jegan Berawan, and Long Teru Berawan. The study has, therefore, its limitations and can only provide an overall impression of the changes that have taken place in the Berawan communities over the last half-century.

\section{METHODOLOGY}

Semi-structured interviews were conducted to interview village leaders and elders from each of the four Berawan communities with the aid of a questionnaire. The questionnaire elicited information on community membership, village occupancy, mode of travel, livelihood, employment, entrepreneurship, longhouse living, entertainment and education in the early 1960s in contrast to the situation in the early 21 st century with an additional question of the future aspirations of the Berawan. The interviewees were natives of the respective villages who remember the situation in the early 1960s from their own experience.

\section{THE BERAWAN COMMUNITIES AND THEIR SETTLEMENTS}

Socio-politically, the Berawan are a sub-group of the Orang Ulu peoples in Sarawak (Metcalf, 2010) and linguistically, they form a separate language family (Burkhardt, 2014; Blust, 1974). The presentday Berawan consist of four communities: the Long Terawan, the Batu Belah, the Long Teru and the Long Jegan community. The first two have their settlements in the Tutoh river system, the latter two in the Tinjar system. Both the Tutoh and the Tinjar are major tributaries of the Baram River in North Sarawak.

The Long Terawan Berawan live in two villages: in Long Terawan, on the Tutoh proper, and in Mulu, along the banks of the Malinau River across from Mulu National Park. The Malinau is a small tributary of the Tutoh. The Tring, who joined the Berawan at Long Terawan in the $19^{\text {th }}$ century, became one community with them but have still kept their own language, which is related to Kelabit (Blust, 1984). The Batu Belah Berawan reside in two settlements, Long Ukuk and Long Patan. The two villages are relatively close to each other and approximately one hour by longboat downriver from Long Terawan. The Long Teru Berawan live in Long Teru and in Sungai Bunen, which is near the Loagan Bunut Lake (Ngidang, Malong \& Egay, 2005). Long Teru is situated on the Tinjar River, about halfway between Lapok and Marudi and the Loagan Bunut Lake, a National Park, is reachable by land in three hours from Miri. The Long Jegan Berawan reside in four villages: Long Jegan, Long Takong, Long Taveng and Long Teran Batu. All four settlements are located on the Tinjar, upriver from Lapok, 
with Long Takong furthest upriver. (See Figure 1). Many Berawan nowadays reside in Marudi, Miri and other cities in Malaysia.

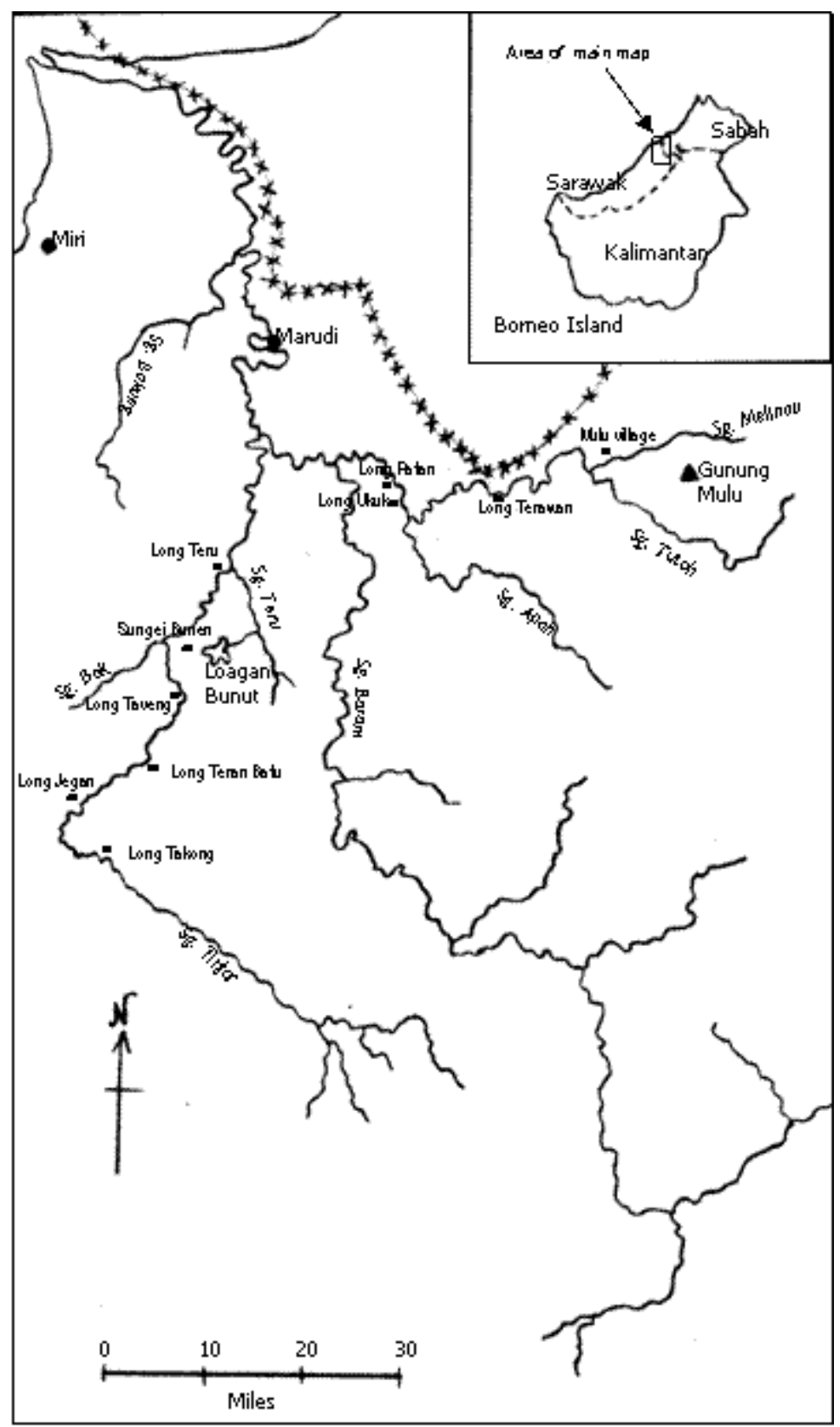

Figure 1. Berawan villages.

\section{FINDINGS}

In this section, we are drawing comparisons between the early 1960s with the present time for all four Berawan subgroups. In doing this, we present our observation in two parts-namely, social organisation, which describes how the Berawan people are organised as a society; and livelihood, which describes their sources of income.

\section{Social organisation}

Village occupancy: The chart below shows the village occupancy of the four Berawan subgroups comparing the two eras. It appears that in the early 1960s the villages were all fully occupied and only a few individuals (six people) left their villages to work elsewhere. In the present time, there is an 
increase in the number of villages, where Long Terawan and Long Teru have split into two villages each and Long Jegan into four villages. However, there appears to be a reduction in actual village occupancy, and it is reported that many more people have started living outside their village as compared to the early days. Most of them have moved to a town within their district (such as Marudi); or to cities elsewhere in Malaysia (for example, Miri, Bintulu or Kuala Lumpur); or even to other countries (such as New Zealand or Canada), although the latter is not common. Table 1 shows the Berawan villages and their occupancy in the early 1960 s compared with the early 21 st century.

Table 1

Comparison of Berawan village occupancy

\begin{tabular}{|c|c|c|}
\hline \multirow{2}{*}{$\begin{array}{l}\text { Berawan } \\
\text { subgroup }\end{array}$} & \multicolumn{2}{|c|}{ Village occupancy } \\
\hline & Early 1960s & Early 21st century \\
\hline \multirow{5}{*}{$\begin{array}{l}\text { Long } \\
\text { Terawan } \\
\text { Berawan }\end{array}$} & & Long Terawan \\
\hline & Long Terawan & 90 apartments, partially occupied \\
\hline & 50 apartments, fully occupied & Mulu \\
\hline & & 30-40 individual houses, fully occupied \\
\hline & $\begin{array}{l}\text { Only } 5 \text { people worked and lived } \\
\text { outside Long Terawan }\end{array}$ & $\begin{array}{l}\text { Many live outside Long Terawan and Mulu, e.g. } \\
\text { in Marudi, Miri, Kuala Lumpur, Brunei, New } \\
\text { Zealand and Canada }\end{array}$ \\
\hline \multirow{9}{*}{$\begin{array}{l}\text { Long Jegan } \\
\text { Berawan }\end{array}$} & & Long Jegan \\
\hline & Long Jegan & 100 apartments, substantially occupied \\
\hline & 30-40 apartments, fully occupied & Long Takong \\
\hline & & 26 apartments, hardly occupied \\
\hline & Long Taveng & Long Taveng \\
\hline & 1 apartment occupied & 37 apartments, substantially occupied \\
\hline & Long Teran Batu & Long Teran Batu \\
\hline & 10 apartments, fully occupied & 26 apartments, substantially occupied \\
\hline & $\begin{array}{l}\text { Nobody lived outside these } \\
\text { villages }\end{array}$ & Many live in Miri and Marudi \\
\hline \multirow{5}{*}{$\begin{array}{l}\text { Batu Belah } \\
\text { Berawan }\end{array}$} & Long Patan & Long Patan \\
\hline & 20 apartments, fully occupied & 30 apartments, partially occupied \\
\hline & Long Ukuk & Long Ukuk \\
\hline & 10 apartments, fully occupied & 30 apartments, partially occupied \\
\hline & $\begin{array}{l}\text { Nobody lived outside these } \\
\text { villages }\end{array}$ & Many live in Miri and Marudi \\
\hline \multirow{3}{*}{$\begin{array}{l}\text { Long Teru } \\
\text { Berawan }\end{array}$} & Long Teru & $\begin{array}{l}\text { Long Teru, } \\
47 \text { apartments, partially occupied }\end{array}$ \\
\hline & 30 apartments fully occupied & $\begin{array}{l}\text { Sungai Bunen, } 35 \text { apartments } \\
\text { partially occupied }\end{array}$ \\
\hline & Nobody lived outside Long Teru & $\begin{array}{l}43.2 \% \text { live outside Long Teru (SLUSE, 2004, } \\
\text { p.12) }\end{array}$ \\
\hline
\end{tabular}

Longhouse living (food, energy and leisure activities): In the past, rice with sago and tapioca were all part of the Berawan staple, which they consumed daily supplemented by meat from animals hunted in the jungle, preferably wild boar. River fish were also consumed regularly. However, they only ate small quantities of vegetables, which were gathered from the jungle.

Nowadays, the Berawan staple is rice, with sago and tapioca only being consumed occasionally by elderly people. The Berawan consume a variety of fruits, vegetables, meat, and fish in their daily diet. This indicates, perhaps, that they are more aware of a healthy lifestyle with a balanced diet. 
Copper lamps (pelita) which use kerosene for fuel were used as their source of light at night. Candles were not available. Firewood and firewood stoves were used for cooking. The source of water for drinking and washing came from the river, and the rivers were said to be clear, clean and good enough to drink from.

Today, every single home has their own diesel generator, which is generally used from $7-10$ $\mathrm{pm}$. While the cost of diesel itself is rather expensive, about two times the price it would cost in urban areas, this is the only source of electric energy in Berawan villages. The widespread use of electrical appliances creates more dependence on diesel generators. Gas cookers are being used for cooking and firewood is only used for barbecuing. Some families have their own washing machines for doing laundry. Clear river water is becoming more difficult to obtain due to the silting of the water caused by logging.

The main leisure activity in the evenings was to tell traditional stories or just talk with each other. Traditional story telling was usually done by older people and their audience was mainly young children. Other leisure activities in the afternoon and evening were weaving baskets, doing bead-work, playing sape (a traditional lute of the Orang Ulu) and singing ballads. Only two or three people in each of the villages had access to radios, and these were not used often. They had trouble keeping up with the necessary supply of batteries and did not have electricians to replace parts or repair these radios when they broke down.

Today, with the use of diesel generators for electricity, every household has its own television set and VCD/DVD player. Watching videos has become the main source of entertainment and leisure activity. There is usually no TV signal in the villages, but some homes have satellite television (e.g., Astro) now and thus access to movies, documentaries and entertainment programmes from around the world.

In terms of infrastructure and accessibility, none of the Berawan villages was connected to urban areas or to other villages by road, and people rarely travelled out of their villages. The only occasion that warranted travelling was when their children started or finished a new school year in a boarding school in town or another village. All the time, villages were using the river as the main mode of transport from one place to another destination whether to neighbouring villages or to urban areas. Thus, every family or household unit had its own paddle boat. Boats with engines were very rare and it was estimated that only three to five of the most influential and financially able families had these. When they had to travel long distances, besides using paddle boats, they also travelled on Chinese junks which came to their villages infrequently. There were airstrips in Long Atip and Marudi for official government use only. Those who flew in still had to travel by river to the Berawan villages.

Berawan villages are more accessible nowadays. The airstrip in Mulu was built in the 1990s, and flying has become the preferred way to travel to Mulu and its national park. Prior to that, tourists and the local community travelled by river. All the Berawan villages also have temporary helipads prepared for special use only. Long Terawan, Long Jegan, Long Teru and both the national parks, Mulu and Loagan Bunut, are accessible by logging roads, using four-wheel-drive vehicles. These logging roads are big enough for timber lorries to transport their goods and are increasingly used by the Berawan themselves. Approximately 30 percent of Long Jegan households have their own motor vehicles to travel by road. Though travel to the villages by road can be long, arduous and even dangerous, it is a very popular mode of transportation for those Berawan that have access to their villages by logging roads. Only the Batu Belah community is not yet accessible entirely by land transport. To reach the two Batu Belah, villages, Long Ukuk and Long Patan one needs to use air or land transport to Marudi first before switching to an express boat or private boat travelling upriver to reach these villages. Express boats started their service along the Baram river system in the 1970s. Until recently, this has been the most popular mode of transportation to reach the Berawan villages and other settlements in the Baram river system. However, due to other available means of transportation, the popularity of the express boats has started to wane so much so that the express boat service from Marudi downriver to Kuala Baram (which then connects by land transport to Miri) was abandoned entirely in mid-2015 (The 
Borneo Post, 2015). This, however, does not create a transportation problem for Berawan settlements which are all located upriver from Marudi. Very few people use paddle boats nowadays. In fact, some of the younger generation do not even know how to navigate one. Every family or household unit has its own outboard engine powered boat nowadays.

Besides infrastructure, education is another theme to be discussed in this qualitative study. There were no schools in Long Terawan and Batu Belah. The Tutoh Berawan sent their children to Long Panai or Marudi for primary school education. Long Jegan and Long Teru had primary schools in the villages from the early 1960s. All who wanted their children to continue their education at the secondary level sent them to Long Lama, Marudi or Tanjung Lobang in Miri.

These days primary school education has improved for the Long Terawan Berawan since there is a primary school in Long Terawan and Batu Bungan at the edge of Mulu National Park. For the Batu Belah, the other Berawan group on the Tutoh, the primary school at either Kuala Tutoh, close to the confluence of the Tutoh with the Baram river, or at Long Panai are within close reach by longboat or express boat. A decade after the primary school at Long Panai was built, a secondary public school named Sekolah Menengah Kebangsaan Tutoh Apoh started operations at the same location. It offers secondary education up to Form three level. Since Long Panai is located on the Tutoh roughly halfway between the Batu Belah settlements and Long Terawan, it offers accessibility to both Berawan communities via longboat or express boat travel (Jau, 2013).

For the Tinjar Berawan, the availability of primary education remains the same as before. In addition, secondary education has come within closer reach since Long Jegan is now connected by road to Lapok and onwards (to Beluru and Miri), which makes the secondary school at Beluru, Sekolah Menengah Kebangsaan (SMK) Bakong, accessible without the necessity of the much more arduous boat travel. SMK Bakong is also the closest secondary school choice for Long Teru pupils nowadays. They would need to travel by longboat or express boat to Lapok first before continuing by land transport to Beluru. Generally, the rural Berawan children are nowadays sent either to Long Panai or Marudi (Tutoh Berawan) or to Marudi and Beluru (Tinjar Berawan) for secondary education. For Berawan pupils living in Miri, there is a wide range of primary and secondary schools available nowadays.

Our interviewees estimated that approximately 80 percent of young Berawan finish primary school as it is compulsory education whereas about 30 percent of them finish secondary school. In 2007, there may have been up to 40 Berawan diploma holders and 30 undergraduate degree holders who have come out of local universities, three Berawan who had completed their postgraduate studies, and one doctoral graduate. This shows that a major change in attitude has taken place over the last forty years in favour of formal education. In fact, primary education has become compulsory since the formation of Malaysia (MyGov, 2008) and as the availability of schools and boarding schools increased, parents were compelled on the one hand and more willing on the other to send their children to school. Having acquired formal education, the young Berawan have been able to participate in the modern cash economy to a greater degree than their parents, securing better-paying jobs and prestige for the family than their parents could. This has produced a change in attitude towards formal education among the Berawan.

\section{Livelihood}

Regarding livelihood,_the main occupation and source of income for the Berawan was subsistence farming, in which a household produced food and raw materials for its own consumption. The Berawan predominantly planted hill rice, though the Long Jegan Berawan also practiced some swamp rice farming. From their rice field cultivation, they usually had a sufficient rice yield for their personal consumption, but at times added tapioca or sago to their diet, which they planted in order to supplement when their rice yield was insufficient. However, they seldom planted vegetables, as most vegetables were gathered from the jungle. The people in Long Teru and Batu Belah also planted some rubber trees, which seemed to be the only cultivated cash crop there. 
In contrast, many people do not live in the villages anymore and only those who still do continue cultivating rice farms, primarily for their personal supply. If there is a surplus yield, they sell their rice in Mulu, Miri or Marudi. In Long Jegan, the people now primarily practice swamp rice cultivation since nowadays, farmable land is scarce and the only available land are flat fields in the immediate vicinity of the longhouse. Furthermore, their rice yield has been gradually decreasing due to pests, and people have resorted to using pesticides. However, The Long Terawan and Batu Belah communities still predominantly practise hill rice cultivation and reported there is still sufficient farmable land available to them to continue the practice of shifting cultivation. In Batu Belah, there appears to be new interest in swamp paddy farming using modern machinery. Furthermore, the Batu Belah leadership is trying to encourage people to start cultivating oil palm and rubber. Private rubber plantations are still found in Long Teru on a small scale, mainly owned and managed by some Berawan themselves. These plantations yield a rather small profit for the owners due to the small volume of latex produced on a small farm. Although there is a desire to run larger scale profitable plantations, the overheads for running larger plantations can be very costly for an individual with limited resources. It would take a concerted effort by the whole longhouse community to successfully implement such an aspiration.

For hunting, the Berawan hunted extensively in the forests surrounding their villages. Their usual methods were to use spears or blowpipes with poisoned darts - the Berawan were particularly skilled in the latter hunting method. Very few people used shotguns which they got from the British government to defend themselves towards the end of the Japanese occupation. They usually had hunting dogs accompanying them into the jungle to track the hunted animals down. The Berawan people seldom hunted deer, mousedeer or other smaller animals because there were a lot of wild boars for hunting and they preferred wild boar meat which they described as tastier than all other types of meat. Monkeys were sometimes hunted if they could not find any wild boars during their hunting trips. Some monkeys were hunted because they had a type of stone in their stomach which fetched a high price from Chinese traders.

However, nowadays it has become increasingly difficult for the Tinjar Berawan to hunt due to the conversion of wide areas of forest into oil palm estates, thus reducing the natural habitat for animals. People still hunt for wild boar, deer or whatever animals that can be found using shotguns instead. They often hunt in small groups with someone who has a licensed gun. There seem to be more hunting activities in the Tutoh, especially in Long Terawan, where people say that there are still plenty of wild boars, unlike in the other Berawan regions, because large-scale plantations have not reached Long Terawan yet. Some families in the Berawan villages now rear cattle and most people rear domestic pigs and poultry, as this provides a readily available supply of meat. The rearing is done small-scale, primarily to meet their own needs.

Moreover, for the matter of fishing, the Berawan are a riverine community who have always been dependent on rivers for transportation and livelihood. These rivers were also a good source for fishing. Although in most Berawan villages farming was the main occupation, Long Teru was practiced fishing as their main occupation. The people used selambau (drag nets) for fishing, and in some cases used tuba (a poisonous root). The use of tuba was usually prohibited by the village leadership. When it was practiced, it was done communally, and everyone in the village was allowed to partake in the catch.

Nowadays, in Long Terawan and Batu Belah, people farm for fish in their own fishpond instead of fishing in the rivers. River fishing has become difficult due to the silting of the rivers and in Long Jegan, people have to travel far to find fish in the rivers, and even then may only catch less than one kilogram of fish. So far, Long Jegan has only two fishponds. Fish farming is reported to be challenging because the ponds are close to the river and are prone to flooding. Once they flood, the fish escape easily. For the Long Teru community, on the other hand, fishing in the river and the Loagan Bunut lake is a major activity with 90 percent of the Berawan families involved in it, mainly to meet their own needs. Ten percent of the community sell fish at the Lapok, which is accessible from Long Teru (Ngidang, Malong, \& Egay, 2005), 
In the past, jungle gathering was extensively practiced, the main products gathered being vegetables, fruit, rattan for making baskets, atap leaves for making thatched roofs, and tree resin for lighting lamps.

Very few items are gathered in the jungle nowadays, apart from a few vegetables (e.g., fern tips, edible shoots) which cannot easily be grown in a vegetable patch. Some jungle products, for example, tree resin, are no longer used in modern day living. In Long Teru, people reported doing more vegetable gathering than in the other villages because frequent flooding makes it difficult to cultivate vegetable gardens there.

Employment: Most Berawan people were subsistence farmers. Only some members of the Long Terawan community had salaried jobs: two were teachers, two were policemen, and one worked for the district office in Marudi.

Today, only a minority of Berawan families are still subsistence farmers. A study by Ngidang (2005) indicated approximately 59.76 percent of the Berawan community at Loagan Bunut (which includes the Long Teru and Sungai Bunen longhouses) are employed outside their villages. Many are educated city dwellers who work in government agencies or petroleum related companies or serve as teachers, school principals, clerical staff or medical staff. There is a large group of Berawan men from the Long Terawan, Long Teru and Long Jegan communities who are employed as lorry drivers, logging workers or mechanics in the local timber companies. Some from Long Teru and Batu Belah work in rubber or oil palm plantations. Many Long Terawan Berawan who live in Mulu are employed in the National Park as park guides and park attendants, some run chalets or restaurants, or are involved in other tourism-related activities.

The Berawan community also ventured themselves in some business and trading. The Berawan traditionally traded with only two groups, which are the Chinese and Penan. Their contact with the Chinese people was through Chinese junks which sailed upriver to the Berawan communities, bringing sugar, clothing, tobacco, bullets, and kerosene which were traded in the old British currency. The Berawan people, in turn, sold goods such as handicrafts, tree resin, surplus rice, meat, and fish. The Berawan also barter traded with the Penan, exchanging cooking pots, tobacco, sugar, salt and kitchen items for the jungle produce of the Penan. There were no business ventures run by the Berawan in those days.

The time of visits by Chinese junks has long passed and the Berawan themselves bring those supplies to their villages as they have more accessibility to the towns. They also run little stores in the villages. Only Long Teru has a resident Chinese shop providing basic supplies. Nowadays, quite a number of Berawan are involved in small business ventures. In Mulu, for example, there are approximately 20 small businesses such as restaurants and grocery shops. In Long Terawan, there are a few small grocery stores attached to the longhouse. One Berawan person, in the oil city of Miri, is involved in trading oil exploration supplies. Another one runs an express boat service in Pulau Pangkor, West Malaysia. In Long Teru, besides selling their catch of fish from the rivers, the Berawan also produce and sell fish crackers (keropok) through the Agriculture Department of Sarawak.

Apart from that, tourism was unheard of by Berawan people in the past. The only contact they had with people from outside, apart from Chinese traders and Penan hunter-gatherers, were occasional visits of government officials and researchers.

Since the 1970s, about 40 Berawan families have moved to live in Mulu to work in the tourism industry. According to the Berawan elders, the Long Terawan Berawan are the custodians of the Mulu National Park, which is their ancestral land. It has been a national park since the 1970s and was recognised as a world heritage site in the year 2000 by UNESCO. The Forestry Department and researchers who come to study the flora and fauna of the Mulu area are often in need of Berawan guides, who are experts in their knowledge of the jungle. The Long Teru Berawan are in a somewhat similar setting with their settlement in Loagan Bunut National Park, which is Sarawak's largest natural lake, 
teeming with fish and surrounded by peat swamp forest and mixed dipterocarp forest, with its equally unique endemic flora and fauna. Loagan Bunut was gazetted as a national park in 1990. Income from tourism earned at Loagan Bunut, however, is rather modest, accounting for only 4.2 percent of the Long Teru community's cash income (Ngidang, Malong \& Egay, 2005).

\section{DISCUSSIONS}

\section{The longhouse-dwelling place of the old and holiday resort of the young}

As a comparison of village occupancy now and then shows, most Berawan still lived in their longhouse communities in the early 1960s, but many of them have since migrated to urban areas. It is mainly the older generation that still resides in the longhouse, whereas the younger generation lives predominantly in urban areas or in timber and plantation camps. Thus, the longhouse has become mainly a holiday resort for the younger generation, who return there during holidays and festivities. In Metcalf's evaluation, the upriver longhouses no longer have "that self-contained air that had made each one its own metropolis [in the past]" and have now rather become "sleeper suburbs of Miri" (2010, p. 309).

\section{Improved infrastructure and accessibility}

Relative isolation due to infrequent travels no longer characterises the longhouse communities. The Berawan travel frequently to trade centres/towns and have a few alternative routes and ways to travel to choose from. Since towns and cities are nowadays within a day's reach or less from the longhouse, many Berawan have started to settle in urban areas. Christmas time, which coincides with the long school holidays in Sarawak, is the time when most young Berawan return to their longhouse for holidays. The improved infrastructure and accessibility have also opened the door for the influx of ideas and influences from the outside world on village living and vice-versa.

\section{Modernisation of longhouse living}

The comfort of living in Berawan longhouses has increased. Now, all households have electric lighting and use gas stoves for cooking. Some households have washing machines, and most households have television and boats with outboard engines. Virtually all households have access to diesel generators to run these modern appliances. This, however, creates more dependency on cash, which has to be provided by family or extended family members who earn cash income, mostly generated outside the village. Thus, a sizable Berawan diaspora working or living outside the village is needed to sustain modern living in the longhouse.

\section{Changes in livelihood}

Traditional activities to ensure livelihood had been the slash-and-burn farming method for rice cultivation, fishing using traps and dragnets, hunting, as well as gathering fruits and vegetables in the jungle. The changes in their landscape and environment have caused a change in the livelihood of the Berawan as well. Once, these slash-and-burn farmers depended on the availability of large areas of land to practice farming and fallowing by rotation. However, since the traditional land surrounding the villages has become environmentally impoverished as a result of logging activities and reduced by the spread of palm oil estates, livelihood out of a traditional subsistence economy is diminished and alternative strategies have had to be employed.

Hunting and jungle gathering are in some places regular activities, but the amount of game, wild fruits and vegetables is significantly less now due to the degradation of the surrounding forest or its conversion into commercial plantations. To meet their meat consumption needs, the Berawan have thus started to rear domestic pigs and cattle. Furthermore, the Berawan have started to plant vegetables and fruit trees and nowadays, only vegetables that cannot be easily planted, such as fern tips and edible shoots, are still gathered in the jungle. The exception is the Long Teru community which depends more on jungle gathering since frequent flooding makes it difficult for them to grow vegetables close to the longhouse. 
The Tutoh and Tinjar Rivers have become silty, which has led to a reduction of the fish population and made the water unsuitable for drinking. To ensure the availability of clean drinking water, water pipes that draw water from smaller, clean rivers were erected with government funding. Moreover, water tanks were installed to catch rainwater. For Long Teru, rainwater tanks are the only source of drinking water. To make up for the declining amount of river fish, the Berawan have started to rear fish in ponds. The exception is the Long Teru community, where river fish are still plentiful and the Loagan Bunut Lake, which is teeming with fish, is also close by.

In the 1960s, every household in the longhouse earned its living through subsistence farming; every family cultivated a rice field. Nowadays, only a minority of households are still engaged in rice farming, mainly done by the older generation. At present, the availability of traditional land for farming is still more or less the same for the Berawan communities on the Tutoh as it was in the 1960s. The Tinjar Berawan, however, find less suitable land for farming and hunting available nowadays since their traditional farming and hunting grounds are increasingly converted into oil palm plantations. This is leading to a gradual erosion of the basis of their traditional livelihood and causes them to seek employment outside their ancestral land.

Overall, the Berawan livelihood has diversified and changed from independent work, that is subsistence farming, to mainly dependent, non-agricultural work in town (oil industry, construction work, and others) or in the logging and plantation industry. There are very few Berawan entrepreneurs in urban areas. Most Berawan enterprises are small business ventures at Mulu National Park, as well as a few fish produce sellers at Long Teru and Lapok. Some Berawan operate four-wheel-drive vehicle transport services to town for Berawan villages that are accessible by road.

\section{Educational advancement}

In education, the Berawan have made significant strides forward in the last 50 years, with about 80 percent of students completing primary school education and about 30 percent completing secondary education. SLUSE (2004) reports similar numbers on the education level for the Berawan longhouse residents at Long Teru. Approximately 75 percent completed primary education including persons that continued with secondary education and 30 percent completed secondary education including STPM and SPM. As of 2007, about 70 persons have received tertiary education.

\section{Rural tourism as a factor that counteracts migration to urban areas}

Migration to urban areas is a very widespread phenomenon in the developing world. Some of the major factors are better education and health facilities, better infrastructure and mobility, a variety of job opportunities, and a higher standard of living in urban areas than in rural ones. Among the Berawan, migration follows the same pattern. An interesting question, therefore, is what motivates people to continue living in rural areas.

For the Berawan, the major factor that motivates people to continue living in their villages and longhouses seems to be the tourism industry. This can be discerned in the case of the Long Terawan Berawan, who live in the vicinity of Mulu National Park. The Mulu National Park, which is part of their traditional native land, gets visited by around 20,000 tourists annually. According to Hului (2015), in 2014 alone, 20,184 tourist visited the park. This has created income-earning opportunities through employment provided by the National Park, as tourist guides, hotel employees, and park rangers. Tourism also creates incentives for erecting small businesses in the service industry, such as offering private accommodation, transportation, and food vendors.

As a result, many Long Terawan Berawan have moved to Mulu and built houses at the fringes of the park. Since the park is not very far from their longhouse (one to three hours per longboat depending on the water level and the direction of travel), there is frequent travel back to the Long Terawan longhouse. Similarly, tourism at Loagan Bunut National Park offers some incentives for the Long Teru community to earn cash and thus continue living there. However, the park was gazetted rather recently (in 1991, 17 years after Mulu) and has only about 3.4 percent of Mulu's annual tourist arrivals "Loagan Bunut - 650 ... Mulu - 19,157 in 2012" (Ministry of Tourism Sarawak, 2014). There 
is no tourism industry in the vicinity of the Batu Belah and Long Jegan settlements. Another factor which would encourage the Berawan to continue living on their ancestral land is the acquisition of formal land titles.

\begin{abstract}
Aspirations
There was a consensus among our interviewees that the Berawan, being a forward-looking people, wish to progress along with the tide of the nation's development. They aspire to further raise their level of education by aiming at one college graduate per longhouse apartment and to modernize their lifestyle in the village. They aspire to learn more about modern agrarian methods to improve their livelihood. Since the basis of their livelihood in the village is the availability and preservation of their ancestral land, the Berawan are striving to secure it for the present and future generations. The Batu Belah community is trying to attain formal land titles on their ancestral land for a wet rice planting scheme as part of a Minor Rural Project (MRP). They expect that the rice planting scheme will encourage their people to migrate back to the village. They are also thinking about ways to start small hold plantations like pepper and palm oil but are in need of expertise on how to do this. Similarly, the Long Terawan community has been striving for many years to attain land titles for their settlement at Mulu National Park. On the first of May 2016, the Sarawak government announced its decision to degazette the part of the Berawan native customary right land which comprises their Mulu settlement, making it principally possible for them to obtain individual land titles (Kiew, 2016). If the government follows through on their promise of granting individual land titles, the move will likely provide an impetus for the other Berawan communities and eventually for other indigenous people groups in Sarawak to give up native customary land rights in favour of individual land titles.
\end{abstract}

\title{
CONCLUSION
}

In this paper, we have compared and contrasted aspects of changes among the Berawan between the early 1960 s and the early 21 st century. We examined changes in social organisation such as village occupancy, longhouse living, infrastructure and accessibility, and education. Furthermore, we looked at changes in livelihood such as farming, hunting, fishing, jungle gathering, employment, business and trading, and tourism.

From this comparison, it can be discerned that the Berawan identity continues to be inseparably linked to their longhouse of origin, even though it has become mainly a holiday resort for the younger generation of Berawan. Modern amenities and better accessibility have improved longhouse living while making it more dependent on cash generated mainly by the urban Berawan diaspora. On the other hand, the reduced amount of animals for hunting and fish in the rivers, as well as the silting of the rivers, have created challenges for the Berawan to get a sufficient supply of meat as well as fish and to secure access to drinking water. The education level of the Berawan has risen significantly in the last 50 years which puts the Berawan in a better position to improve their livelihood and overcome those challenges on the one hand but also gives them better access to employment in urban centres on the other. The reduction and impoverishment of their traditional planting, hunting and fishing grounds coupled with educational advancements are the main factors that have caused Berawan migration to other areas, especially urban centres. The Berawan still practise traditional subsistence farming on their ancestral land, albeit on a reduced scale, and it is mainly the older generation that cultivates the fields. Last and not the least, the gazetting of National Parks on Berawan ancestral land and the resulting job and business opportunities in tourism have motivated a considerable number of Berawan to continue living on their ancestral land. Thus, tourism appears to be a major factor that lessens the migration from rural to urban areas. If the Berawan can succeed to launch agricultural initiatives like the small-scale rural project or plantations, and at the same time acquire formal land titles on their traditional land, this could become another major factor in the future to motivate the Berawan to continue living on their ancestral land or to migrate back from the city to the village. 


\section{REFERENCES}

Blust, R. A. (1974). The Proto-North Sarawak vowel deletion hypothesis. (Doctoral thesis). University of Hawaii, Manoa, Hawaii.

(1984). The Tring dialect of Long Terawan, Sarawak Museum Journal 54:101-135.

Burkhardt, J. M. (2014). The reconstruction of the phonology of Proto-Berawan. (Doctoral thesis). Goethe University, Frankfurt, Germany.

Hudson, A. (1977). Linguistic relations among Bornean peoples with special reference to Sarawak: An interim report. Studies in Third World Societies 3:1-44.

Hului, P. (2015, April 24). Mulu national park tourist arrivals steady. The Borneo Post online. Retrieved from http://www.theborneopost.com/2015/04/24/mulu-national-park-touristarrivals-steady/

Jau, H. (2013, November 5). SMK Tutoh now more than 50\% completed. The New Sarawak Tribune. Retrieved from http://www.newsarawaktribune.com/news/14629/SMK-Tutoh-now-morethan-50-completed/

Kiew, P. (2016, May 04). Berawans to have NCR land de-gazetted from Mulu National Park. The Borneo Post online. Retrieved from http://www.theborneopost.com/2016/05/05/berawans-tohave-ncr-land-de-gazetted-from-mulu-national-park/

Metcalf, P. (1975). The distribution of secondary treatment of the dead in Central Borneo. Brunei Research Bulletin 7(2), 54-59.

(July, 1993). Room of origin: What the idea has meant in the past, and might mean in the future. Paper presented at the Orang Ulu Cultural Seminar, Marudi, Sarawak.

(2010). The life of the longhouse. An archeology of ethnicity. Cambridge: Cambridge University Press.

Ministry of Tourism Sarawak (2014). Sarawak tourism quick facts 2013. Retrieved from http://www.mtac.sarawak.gov.my/upload/file_folder/Real\%20Sarawak\%20Tourism\%20Quic k\%20Facts\%202013.pdf

Ngidang, D., Malong R. \& Egay, K. J. (June, 2005). Social space and livelihood of indigenous communities in the Loagan Bunut National Park, Tinjar, Sarawak. Paper presented at the International Symposium of Society and Resource Management, Ostersund, Sweden.

SLUSE ILUNRM. (2004). Impacts of land development on livelihood strategies in Rumah Kajan. Retrieved from http://sluse.dk/courses/ilunrm/project/03_04_ma_rh_kajan

Soda, R. (2003). Development policy and human mobility in a developing country: Voting strategy of the Iban in Sarawak, Malaysia. The Southeast Asian Studies, 40(4), 459-483. Retrieved from http://ci.nii.ac.jp/els/110000281284.pdf?id=ART0000718658\&type=pdf\&lang=en\&hosh=cini i\&order_no $=\& p p v \_t y p e=0 \& l a n g \_s w=\& n o=1486352753 \& \mathrm{cp}=$

The Borneo Post Online (2015, August 28). Baram folk lament cancellation of express boat service. Retrieved February 6, 2017, from http://www.theborneopost.com/2015/08/29/baram-folklament-cancellation-of-express-boat-service

The Malaysian Government Official Portal. (2008). Primary School Education. Retrieved May 07, 2008, from http://www.gov.my/MyGov/BI/Directory/Citizen/Education/PrimarySchool/

WELCOME TO LONG PANAI TUTOH BLOGSPOT. (1970, January 01). Retrieved February 05, 2017, from http://longpanai.blogspot.my/ 